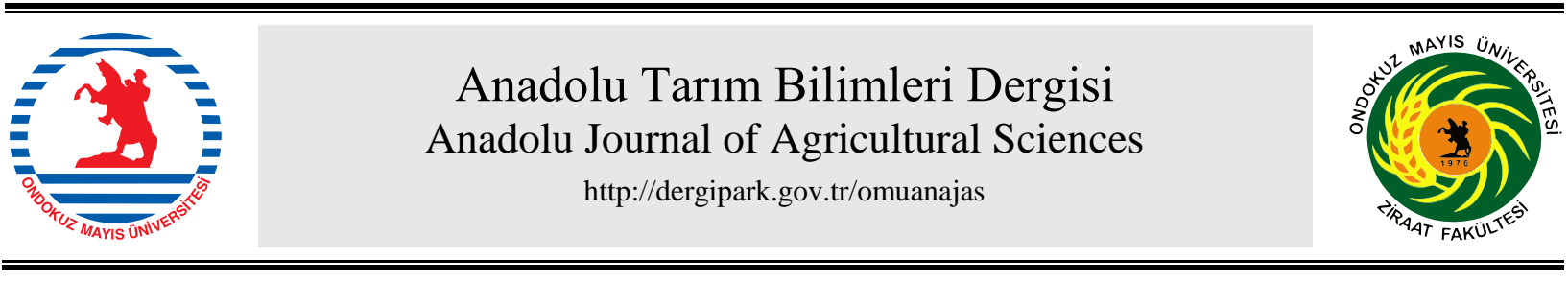

Araştırma/Research

Anadolu Tarım Bilim. Derg./Anadolu J Agr Sci, 32 (2017)

ISSN: 1308-8750 (Print) 1308-8769 (Online)

doi: 10.7161/omuanajas.280516

\title{
Farklı sulama suyu tuzluluk seviyelerinin keten (Linum usitatissimum L.)'in çimlenme ve erken fide gelişimi üzerine etkisi
}

\author{
M. Sait Kiremit ${ }^{\mathrm{a}^{*}}$, M. Safa Hacıkamiloğlu ${ }^{\mathrm{b}}$, Hakan Arslan $^{\mathrm{a}}$, Orhan Kurt ${ }^{\mathrm{b}}$ \\ ${ }^{a}$ Ondokuz Mayls Üniversitesi, Ziraat Fakültesi, Tarımsal Yapılar ve Sulama Bölümü, 55139 Kurupelit, Samsun \\ ${ }^{b}$ Ondokuz Mayls Üniversitesi, Ziraat Fakültesi, Tarla Bitkileri Bölümü, 55139 Kurupelit, Samsun \\ "Sorumlu yazar/corresponding author: mehmet.kiremit@omu.edu.tr
}

Geliş/Received 27/12/2016 Kabul/Accepted 06/09/2017

\begin{abstract}
ÖZET
Bu çalışmada; farklı sulama suyu tuzluluk düzeylerinin(0.38 (kontrol), 1, 2, 3, 4, 5, 6, 7, 8, 9, $10 \mathrm{dS} \mathrm{m}^{-1}$ ) keten tohumlarının çimlenme hızı, çimlenme oranı, sürgün ve kök uzunlukları, sürgün yaş ve kuru ağırlığı, kök yaş ve kuru ağırlığ 1 üzerine etkileri incelenmiştir. Araştırma sonuçlarından tohum çimlenme hızı, çimlenme oranı ve tuz toleransı indeksi değerlerinin sırasıyla \% 52.2-76.0, \% 66.5-97.0,

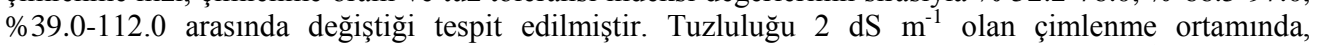
incelenen tüm gelişim parametrelerinin en iyi değere ulaştığ ve tuzluluk düzeyinin $2 \mathrm{dS} \mathrm{m}^{-1}$, den yüksek olduğu koşullarda ise tohum çimlenmesi ve erken fide gelişim parametrelerinin olumsuz yönde etkilendiği belirlenmiştir. Bununla birlikte, araştırma sonucu incelenen bütün parametreler dikkate

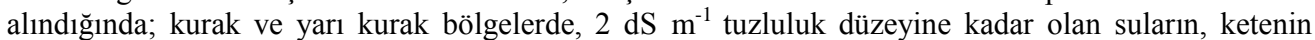
çimlenme ve erken fide gelişim dönemlerinde kullanılabileceği tespit edilmiştir.
\end{abstract}

The effects of different irrigation water salinity levels on germination and early seedling development of flax (Linum usitatissimum L.)

\section{ABSTRACT}

In the the present study, the effects of different irrigation water salinity levels ( 0.38 (control), 1, 2, 3, 4, $5,6,7,8,9,10 \mathrm{dS} \mathrm{m}^{-1}$ ) on germination speed, germination rate, shoot and root lengths, shoot wet and dry weights, root wet and dry weights of flax seed were investigated. The germination speed, germination rate and salt tolerance index changed between 52.2-76.0 \%, 66.5-97.0\% and 39.0-112.0\%, respectively. All the development parameters attained the best values in germination medium with $2 \mathrm{dS}$ $\mathrm{m}^{-1}$ salinity. However, the salinity levels higher than $2 \mathrm{dSm}-1$ had negative effect on seed germination and early seedling development parameters. When all of the parameters were taken into consideration it was noted that irrigation water with up to $2 \mathrm{dS}$ m-1 salinity can be used for flax seed germination and early seedling development in arid and semi-arid regions.

Anahtar Sözcükler: Tohum çimlenmesi Tuzlu sulama suyu Tuz stresi Yağlı tohum

\section{Giriş}

Son yıllarda, Dünyamızın karşı karşıya olduğu küresel 1sınma sorununun en belirgin etkisi yağış miktarlarındaki düzensizlikler ile kendini göstermektedir. Bu durum; su kaynaklarının kıt olduğu bölgelerde, uygun olmayan su kaynaklarının tarımsal faaliyetlerde kullanılmasina neden olmaktadır. $\mathrm{Bu}$ nedenle bir çok araştırıcı tarafindan uygun olmayan su kaynaklarının kullanılabilme olanakları araştııılmıştır (Odabaş ve ark., 2014; Temizel ve ark., 2014; Temizel, 2015). Kurak ve yarı kurak bölgelerde düşük kalitedeki atık suların, drenaj ve nehir sularının tarımsal üretimde yanlış ve yoğun kullanımları, tarım arazilerinde tuzluluk probleminin ortaya çıkmasına neden olmaktadır. Dünya genelinde 800 milyon hektar alanda tuzluluk sorunu bulunmaktadır (Munns, 2005). Ülkemizde sulanan alanların yaklaşık \% 32.5'i tuzluluktan etkilenmektedir (Ekmekçi ve ark., 2005). Bitki büyüme ve gelişimi üzerinde etkili olan önemli çevresel stres faktörlerinden birisi de tuz stresidir. Bitkilerin tuz stresine karşı tepkileri incelendiğinde; her bitki grubunun, tuza karş1 dayanımının, farklı olduğu anlaşılmaktadır (Levitt, 1980; Turhan ve Başer, 2001). 
Her bitki, büyüme ve gelişme devrelerinde yetişme ortamındaki tuz stresinden etkilenmektedir. Bitkilerin tuz stresine karşı en duyarlı olduğu dönem çimlenme dönemidir (Kuşvuran ve ark., 2007; Yıldız ve ark., 2007; Zamani ve ark., 2010). Toprak içerisindeki yüksek tuz konsantrasyonu, tohumun çimlenmesini engellemekte veya düşük seviyelerde dormansinin başlamasına sebep olmaktadır. Tuz, toksin etkisinden dolayı enzimatik aktivitelerin değişmesi gibi birçok fizyolojik ve metabolik düzeyde zarar yaparak tohumun çimlenmesini olumsuz yönde etkilenmektedir (Çulha ve Çakırlar, 2011).

Keten bitkisi tuzluluğa karşı orta düzeyde toleranslı bir bitki olup, toprak tuzluluğu sirasıyla $2.5,3.8$ ve 5.9 $\mathrm{dS} \mathrm{m}^{-1}$ olduğunda; verimde $\% 10, \% 25$ ve $\% 50$ oranında azalma olmaktadır (Ayers ve Westcot, 1989). Gholizadeh ve ark. (2016), 0, 4, 8 ve $12 \mathrm{dSm}^{-1}$ tuzlu suların çimlenme dönemindeki keten, enginar, aspir ve ekinezya tohumlarının tuz toleransını ve morfolojik özellikleri üzerine etkilerini belirlemek amaciyla yaptıkları araştırmada; çimlenme döneminde keten ve aspir tohumlarının tuz stresine karşı ekinezya ve enginar tohumlarına göre daha çok tolerans gösterdiğini, tuzluluk arttıkça araştırmada ele alınan bütün bitkilerde çimlenme oranının, sürgün ve kökçük uzunluğu ile bitki kuru ağırlığının azaldığını tespit etmişlerdir. Tabatabaei ve Angholi (2012), tuzluluk düzeyinin $10 \mathrm{dSm}^{-1}$, den daha fazla artması yemlik sorgum çeşitlerinin çimlenme oranlarında önemli derecede azalmaların gerçekleştiğini ve tuzluluğun artmasıyla birlikte bazı sorgum çeşitlerinin kök ve gövde uzunluklarının da azaldığını belirlemişlerdir. Aydınşakir ve ark. (2012), silajlık sorgum çeşitlerinde (Early Sumac, Leoti, Nes ve Rox) çimlenme ve fide gelişimi üzerine etkilerini incelemek için farklı NaCI konsantrasyonları $(0,2,4,6,8,10$ $\mathrm{dSm}^{-1}$ ) uygulamışlardır. Çalışma sonucunda tuzluluk seviyesi arttıkça çeşitlerin erken fide dönemi özellik değerlerinin azaldığını ve tuz stresine karşı en toleranslı çeşidin Early Sumac, en hassas çeşidin ise Nes olduğunu tespit etmişlerdir. Aydinşakir ve ark. (2013), farklı $\mathrm{NaCI}$ dozlarının (0 (kontrol), 2, 4, 6, 8 ve $10 \mathrm{dS}$ $\mathrm{m}^{-1}$ ) 4 farklı silajlık mısır çeşitlerinin (Burak, Efe, Hido ve Şafak) çimlenme ve erken fide gelişimi üzerine etkilerini araştırdıkları çalışmada, tuz stresi arttıkça çimlenme oranı ve çeşitlere göre erken fide gelişimi üzerinde önemli azalmaların meydana geldiğini bulmuşlardır. Çalışma sonucunda tuz stresine karşı toleransı en yüksek olan Hido çeşidinin, tuza karşı en hassas olanı ise Efe çeşidinin olduğunu tespit etmişlerdir. Uyanık ve ark. (2014), 8 farklı NaCI dozlarının $(0,25,50,75,100,125,150$ ve $200 \mathrm{mM}) 4$ farklı kışlık kolza çeşitlerinin (Egc7571, Elvis, Es Hydromel ve Triganle) çimlenmesi üzerine etkilerini belirlemek için yaptıkları çalışmada; kışlık kolza çeşitlerinin çimlenme oranı bakımından $125 \mathrm{mM} \mathrm{NaCI}$ dozuna kadar tolerans gösterebilmiş, bu düzeyden sonra tuz stresi arttıkça çimlenme oranında önemli azalmalarının meydana geldiğini, Egc 7571 çeşidinin tuz stresine diğer kışlık kolza çeşitlerine göre daha toleranslı olduğunu belirtmişlerdir. Önal Aşçı ve Üney (2016), farklı tuz yoğunluğunun $(0,25,50,75,100$, $125,150,175,200,225,250,275$ ve $300 \mathrm{mM} \mathrm{NaCl}$ ) Ege Beyazı-79 macar fiği (Vicia pannonica Crantz) üzerine etkilerini araştırdıkları çalışmada, $25 \mathrm{mM} \mathrm{NaCI}$ uygulamasının toprak üstü yaş ve kök yaş ağırlıklarını teşvik ettiğini, $100 \mathrm{mM}$ tuz seviyesinden sonra önemli derecede olumsuz etkiye neden olduğunu belirlemişlerdir.

Yağ ve lif elde etmek amaciyla yetiştirilen keten bitkisinin tohumu \% 35-45 oranında yağ içermektedir. Türkiye'nin 2015 yılına ait yağlı tohum üretimi verilerine göre 8.661 milyon dekar alanda yetiştiricilik yapılmış ve 3.442 milyon ton üretim gerçekleşmiştir (TÜİK, 2015). 2014 yılı verilerine göre Türkiye yağlı tohum ve türevleri ithali için 4.3 milyar dolar döviz ödemiş olup bu miktar petrolden sonra en fazla ödenen ithalat kalemidir. Türkiye sahip olduğu avantajlı coğrafik ve tarımsal koşullara rağmen bitkisel yăg üretimi için ihtiyaç duyulan yağ bitkileri üretimini gerçekleştirememektedir. Bütün teşvik unsurlarına rağmen arzu edilen üretim hedefine ulaşılamamaktadır.

Türkiye'de ham yağ veya yağlı tohum ihtiyacını karşılayacak düzeyde üretim gerçekleştirebilmek ve dişa bağımlılığı azaltabilmek için yağ bitkilerinin ekim alanlarının genişletilmesi yanında keten, kamelina ve krambe başta olmak üzere diğer yağ bitkilerinin de üretim deseni içindeki yerlerini ivedi olarak yer alması gerekir (Kurt, 1996; Bozkurt ve Kurt, 2007). Üretim deseni içinde yer alan yă bitkilerinin de üretimini sınırlandıran veya azaltan faktörlerin ortadan kaldırılması gerekir. Bu amaca yönelik olarak; bitkisel üretimi sınırlandıran faktörlerden birisi olan bitkinin büyüme ve gelişme dönemlerindeki tuz stresine karş1 tepkisinin belirlenmesi, sürdürülebilir ve ekonomik üretim için önemli yarar sağlayacağı düşüncesi ile bu araştırma yürütülmüştür.

\section{Materyal ve Yöntem}

Antares keten (Linum usitatissimum L.) çeşidi tohumların çimlenme döneminde farklı tuz stresine tepkilerini belirlemek amaciyla yapılan bu çalışma; Ondokuz Mayıs Üniversitesi, Ziraat Fakültesi, Tarla Bitkileri Bölümü laboratuvarlarında, 2016 yılında yürütülmüştür. Çalışma, tesadüfi parseller deneme desenine göre 4 tekerrürlü olarak yürütülmüş ve tohumlara 11 farklı tuzlu su (0.38 (kontrol), 1, 2, 3, 4, 5, $6,7,8,9$ ve $10 \mathrm{dS} \mathrm{m}^{-1}$ ) uygulanmıştır. Tuzlu suları elde edebilmek için suda eriyebilirlikleri yüksek olan $\mathrm{NaCI}$, $\mathrm{MgSO}_{4}$ ve $\mathrm{CaCI}_{2}$ tuzları kullanılmıştır. Sulama sularında istenen tuz değerinin belirlenebilmesi için kontrol suyuna eklenmesi gereken tuz miktarı QBASIC programında hesaplanmış ve tüm konularda Sodyum Adsorbsiyon Değerinin (SAR) etkisini ortadan kaldırmak için bu değerin 3 'den düşük olması sağlanmıştır. Denemeye başlamadan önce, QBASIC programında hesaplanan tuz miktarları laboratuvarda denenerek, suların elektriksel iletkenlik (EC) değerleri 
kontrol edilmiştir.

Çimlenme çalışması öncesinde, tohumların yüzey sterilizasyonunu sağlamak için \% 5 'lik Sodyum Hipoklorit çözeltisinde 10 dakika süre ile sterilize edilmiştir. Sterilize edilmiş tohumlar; $9 \mathrm{~cm}$ çapında, cam petri kaplarina, her petri kabında 50 adet tohum olacak şekilde, kapların tabanına konan 2 tabaka filtre kâğıdı (Whatman's No:1) üzerine, cımbız yardımıyla ekilmiştir (Nizam, 2011). Her petri kabına, konusuna göre, laboratuvarda hazırlanmış tuzlu su solüsyonlarından $10 \mathrm{ml}$ eklenmiştir. Petri kaplarında tuz birikimini önleyebilmek için filtre kâğıtları 2 gün aralıklar ile değiştirilmiştir (Rehman ve ark., 1996). Petri kaplarındaki olası buharlaşmayı önlemek için petri kaplarının üzeri cam kapak ile kapatılmıştır. Cimlendirme kapları iklimlendirme dolabına alınarak, ortalama 12 saat süreyle 12000 lüx 1 şı, ortalama $25 \pm 1^{\circ} \mathrm{C}$ sicaklık ve $\% 70$ nem oranının etkisinde 14 gün boyunca iklimlendirme dolabında, çimlenmeye bırakılmıştır.

Denemenin 1, 2, 3, 5 ve 7'inci günlerinde çimlenen tohumlar sayılmış ve "Uluslararası Tohum Test Birliğì" kurallarına göre $2 \mathrm{~mm}$ kökçük uzunluğuna sahip olan tohum, çimlenmiş olarak kabul edilmiştir (ISTA, 1993). Üçüncü günün sonunda çimlenen tohumlar, toplam tohum sayısına oranlanarak çimlenme hızı (\%), 7'inci günün sonunda ekilen ve çimlenen tohumlar oranlanarak çimlenme oranı değeri belirlenmiştir. 14 günlük test süresi sonunda ise tohumların sürgün yaş ağırlığı, kök yaş ağırlığı, sürgün uzunluğu ve kök uzunluğu belirlenmiştir. Sürgün ve kök yaş ağırlıkları, her petri kabından tesadüfi olarak seçilen 10 örneğin tartılması ile belirlenmiştir. Sürgün uzunluğu ve kök uzunlukları ise tesadüfi olarak seçilmiş 10 fidenin 1/1 oranında fotoğrafının çekilerek bilgisayar ortamına alınması ve daha sonra Image J programı kullanılarak, ölçülüp ortalamasının alınmasıyla belirlenmiştir. Sürgün ve kök kuru ağırlıklarını belirlemek için sürgün ve kökler kurutma dolabında $70{ }^{\circ} \mathrm{C}$ 'de 24 saat kurutulduktan sonra hassas terazide tartılmış ve ağırlıkları mg olarak kaydedilmiştir (ISTA, 1993). Farklı tuzluluk düzeylerine göre keten tohumlarının tuz toleransı indeksi (TTI)'nin belirlenmesinde aşağıdaki "Eşitlik 1" kullanılmıştır (Matwijcuk ve ark., 2012).

TTİ $(\%)=\frac{\text { Sx konusundaki (sürgün+kök kuru ağırlığı) }}{\text { So (kontrol) konusundaki (sürgün+kök kuru ağırlığı) }}$

$\mathrm{S}_{\mathrm{x}}$ : Tuzlu su uygulamasındaki bitki kuru ağırlı̆̆

$\mathrm{S}_{\mathrm{o}}$ : Kontrol konusundaki bitki kuru ağırlığ 1

Transformasyon sonrası verilerin istatistiksel analizi, SPSS 21.0 istatistik paket programı kullanılarak yapılmıştır. Grupların ortalamaları arasındaki farkın önemlilik kontrolü LSD testi ile belirlenmiştir. Fide gelişimi parametreleri arasındaki ilişki için Pearson Korelasyon Analizi kullanılmıştır.

\section{Bulgular ve Tartışma}

Farklı sulama suyu tuzluluk düzeylerinin ketenin çimlenme oranı, çimlenme hızı ve tuz toleransı indeksi üzerine etkileri Çizelge 1'de verilmiştir. Farklı sulama suyu tuzluluk seviyelerinin incelenen tüm parametreler üzerine etkisinin $\mathrm{P}<0.01$ düzeyinde önemli olduğu tespit edilmiştir.

\section{1. Çimlenme oranı}

Çizelge 1 incelendiğinde; keten tohumlarının artan tuzluluk koşullarından önemli derecede etkilendiği ve çimlenme oranının \% 66.5 ile \% 97.0 arasında değişim gösterdiği belirlenmiştir. En yüksek çimlenme oran 2 $\mathrm{dSm}^{-1}$ tuzluluk düzeyinden, en düşük çimlenme oranı ise $10 \mathrm{dSm}^{-1}$ tuzluluk düzeyinden elde edilmiştir. LSD testine göre 0.38 (kontrol), 1, 2, 3 ve $4 \mathrm{dS} \mathrm{m}^{-1}$ tuzluluk düzeyleri aynı grupta olup, çimlenme oranları arasındaki farkın istatistiksel olarak önemli olmadığı belirlenmiştir. Bu durum, keten tohumlarının çimlenme ortamındaki tuz yoğunluğunun $4 \mathrm{dSm}^{-1}$ düzeyine kadar dayanıklı olduğunu göstermektedir. Çalışmada; 0.38 (kontrol) $\mathrm{dSm}^{-1}$ ile $2 \mathrm{dS} \mathrm{m}^{-1}$ tuzluluk düzeyleri arasında çimlenme oranı bakımından \% 2.0'lik fark olmasına karşın, kontrol ile $10 \mathrm{dSm}^{-1}$ tuzluluk düzeyi arasında \% 30.0'luk bir farklılığın olduğu belirlenmiştir.

Çimlenme ortamında düşük düzeyde bulunan $\mathrm{Na}^{+}$, $\mathrm{Cl}^{-}$ve diğer çözülebilir tuz iyonları, toksik etki oluşturmadan, çimlenmeyi teşvik etmektedir (Kaya ve ark., 2003; Mahmoodzadeh, 2008). Çimlenme oranının azalması, yüksek tuzluluk düzeyinin su alımını engellemesi, tuz iyonlarının toksik etki oluşturması ve çimlenmenin gerçekleşmesi için gerekli olan enzimlerin tuz stresinden dolayı aktif hale gelememesinin neden olduğu ifade edilmektedir (Mansour, 1994; Sadeghian ve Yavari, 2004). Stres koşulları altında çimlenmenin yavaşlaması veya durması tohumların stresli ortamdan kendilerini korumaya yönelik adaptif strateji olabileceği belirtilmektedir (Gill ve ark., 2003). Kuraklık ve tuz stresi koşullarında, ozmotik stres etkisi ile tohumlardaki çimlenmenin durması veya yavaşlaması sonucu çimlenme oranında azalma meydana geldiği söylenebilir.

Elde edilen veriler 1şığında, $2 \mathrm{dS} \mathrm{m}^{-1}$ tuzluluk düzeyine kadar tuz iyonları toksik etki oluşturmadan keten tohumlarının çimlenmesini teşvik ettiği ve bu düzeyden sonra tuzluluk düzeyi arttıkça keten tohumlarının tuza karşı toleransının azalmasıyla birlikte çimlenme oranında azalmanın gerçekleştiği söylenebilir.

Çimlenme oranının azalmasına yüksek tuz konsantrasyonunun su alımını engellemesi, tuzun toksik etki yapması ve çimlenme sırasında gerekli olan enzimlerin tuz stresinden dolays aktif hale gelememesinin neden olduğu bildirilmektedir (Mansour, 1994; Essa, 2002; Sadeghian ve Yavari, 2004). 


\section{2. Çimlenme hızl}

Çalışma sonucunda tuzluluk düzeyleri ile çimlenme hızı arasında $\% \quad 1$ düzeyinde önemli bir ilişki bulunmuştur (Çizelge 1). Keten tohumlarının çimlenme hızı değerlerinin \% 52.3 ile \% 77.5 arasında olduğu ve 0.38 (kontrol), 1, 2, 3, 4 ve $5 \mathrm{dS} \mathrm{m}^{-1}$ tuzluluk düzeylerindeki keten tohumlarının çimlenme hızları arasındaki farkın istatistiksel olarak önemli olmadığı, en yüksek çimlenme hızının ise $2 \mathrm{dS} \mathrm{m^{-1 }}$ uygulamasında olduğu belirlenmiştir. Elde edilen verilere göre, tohumların çimlenme hızı üzerine ortamdaki ozmotik ve tuz stresinin, bazı elementlerin toksitesinin ve besin eksikliğin etkili olduğu düşünülmektedir. Bitkilerde ikincil stresler olarak; oksidatif stres ve bazı iyon toksitesine bağlı olarak fizyolojik belirtiler; membran geçirgenliğinde azalma ve organellerin zarar görmesi, bunun sonucunda enzimsel aktivitesinde azalma ve kısıtlanma ile stres hormonlarında değişim meydana gelmektedir (Castroluna ve ark., 2014).
Elde edilen verilere göre; keten tohumlarının çimlenme hızının $5 \mathrm{dS} \mathrm{m}^{-1}$ tuzluluk düzeyine kadar olan tuzluluk seviyelerinden önemli derecede etkilenmediğ $i$ belirlenmiştir.

\subsection{Tuz toleransl indeksi (TTi)}

Keten tohumlarının çimlenme ortamındaki farklı tuzlu koşulların tuz toleransı indeksine etkilerine ilişkin veriler Çizelge 1'de verilmiştir. En yüksek tuz toleransı indeksi değeri $\% \quad 112.0$ ile $2 \mathrm{dSm}^{-1}$ tuzluluk seviyesinden elde edilirken, en düşük tuz tolerans1 indeksi değeri ise $\% 39.0$ ile $10 \mathrm{dSm}^{-1}$ tuzluluk seviyesinden elde edilmiştir. Elde edilen veriler incelendiğinde; tuzluluk seviyesi $2 \mathrm{dSm}^{-1}$ den $10 \mathrm{dSm}^{-}$ ${ }^{1}$ ye çıkarıldığında keten tohumlarının tuz toleransı indeksinde \% 73.0 oranında azalma olduğu belirlenmiştir. Çiftçi ve ark. (2013)'de yapmış oldukları çalışmada tritikalede tuz konsantrasyonunun artmasıyla tuz toleransı indekslerinin azaldığını belirlenmişlerdir.

Çizelge 1. Sulama suyu tuzluluk düzeylerinin ketenin çimlenme oranı, çimlenme hızı ve tuz toleransı indeksine etkileri

\begin{tabular}{|c|c|c|c|c|c|c|}
\hline \multirow{2}{*}{ 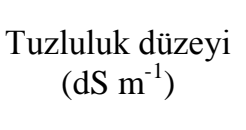 } & \multicolumn{6}{|c|}{ İncelenen Parametreler } \\
\hline & $\begin{array}{l}\text { Çimlenme } \\
\text { Oranı (\%) }\end{array}$ & $\begin{array}{l}\text { Değişim } \\
(\%)\end{array}$ & $\begin{array}{l}\text { Çimlenme } \\
\text { hızı (\%) }\end{array}$ & $\begin{array}{l}\text { Değişim } \\
(\%)\end{array}$ & $\begin{array}{l}\text { Tuz tolerans1 } \\
\text { indeksi }(\%)\end{array}$ & $\begin{array}{l}\text { Değişim } \\
(\%)\end{array}$ \\
\hline 0.38 & $95.5^{\mathrm{ab}}$ & 100 & $75.0^{\mathrm{ab}}$ & 100 & $100.0^{\mathrm{b}}$ & 100 \\
\hline 1 & $95.0^{\mathrm{ab}}$ & 99 & $75.5^{\mathrm{ab}}$ & 101 & $108.0^{\mathrm{ab}}$ & 107 \\
\hline 2 & $97.0^{\mathrm{a}}$ & 102 & $77.5^{\mathrm{a}}$ & 103 & $112.0^{\mathrm{a}}$ & 111 \\
\hline 3 & $96.0^{\mathrm{ab}}$ & 101 & $76.0^{\mathrm{ab}}$ & 101 & $82.0^{c}$ & 82 \\
\hline 4 & $90.5^{\mathrm{ac}}$ & 95 & $73.0^{\mathrm{ac}}$ & 97 & $69.0^{\mathrm{d}}$ & 69 \\
\hline 5 & $89.5^{\mathrm{bc}}$ & 94 & $71.5^{\mathrm{ac}}$ & 95 & $65.0^{\mathrm{d}}$ & 65 \\
\hline 6 & $86.5^{\mathrm{c}}$ & 91 & $70.3^{\mathrm{bc}}$ & 94 & $63.0^{\mathrm{d}}$ & 63 \\
\hline 7 & $85.5^{\mathrm{cd}}$ & 90 & $70.0^{\mathrm{bc}}$ & 93 & $59.0^{\mathrm{de}}$ & 58 \\
\hline 8 & $79.0^{\mathrm{de}}$ & 83 & $67.0^{\mathrm{cd}}$ & 89 & $53.0^{\mathrm{ef}}$ & 53 \\
\hline 9 & $77.5^{\mathrm{e}}$ & 81 & $62.8^{\mathrm{d}}$ & 84 & $45.0^{\mathrm{fg}}$ & 45 \\
\hline 10 & $66.5^{\mathrm{f}}$ & 70 & $52.3^{\mathrm{e}}$ & 70 & $39.0^{\mathrm{g}}$ & 38 \\
\hline LSD & $7.08^{*}$ & & $7.10^{*}$ & & $10.42^{*}$ & \\
\hline VK & 5.63 & & 7.02 & & 10.00 & \\
\hline
\end{tabular}

*, P<0.05; VK, Varyasyon Katsayısı (\%); Aynı sütunda farklı harfler ile gösterilen ortalamalar arasında fark vardır.

\subsection{Sürgün ve kök yaş ăğrlıklarl}

Sulama suyu tuzluluk seviyelerinin Antares keten (Linum usitatissimum L.) çeşidinin sürgün ve kök yaş ağırlığı üzerine etkilerine ilişkin verileri Çizelge 2'de verilmiştir. Sürgün ve kök yaş ağırlıklarının farklı sulama suyu tuzluluk seviyelerine göre değişiminin istatistiki olarak $(\mathrm{P}<0.01) \quad$ önemli olduğu tespit edilmiştir. Tuzluluk düzeyine göre sürgün yaş ağırlıkları $319 \mathrm{mg}$ ile $635 \mathrm{mg}$ arasında, kök yaş ağırlıkları ise 77 mg ile $291 \mathrm{mg}$ arasında değişim göstermiştir. En yüksek sürgün ve kök yaş ağırlıkları $2 \mathrm{dS} \mathrm{m}^{-1}$ tuzluluk düzeyinden elde edilirken, en düşük sürgün ve kök yaş ağırlıkları ise $10 \mathrm{dS} \mathrm{m}^{-1}$ tuzluluk düzeyinden elde edilmiştir. Sulama suyu tuzluluğunun $2 \mathrm{dS} \mathrm{m}^{-1}$ seviyesine kadar artırılması durumunda sürgün ve kök yaş ağırlıklarının artarak en yüksek değerlere ulaştığı, 2 $\mathrm{dSm}^{-1}$ 'den daha yüksek tuz seviyelerinde ise sürgün ve kök yaş ağırlıklarının azaldığı belirlenmiştir. Kaya ve ark. (2005), düşük $\mathrm{NaCl}$ tuz düzeylerinde bazı bitkilerin kök yaş ağırlığında artış olabileceğini bildirmektedirler. Nizam (2011), yaptığ bitkisinin erken fide döneminde 2 , 4 ve $8 \mathrm{dS} \mathrm{m}^{-1}$ tuzluluk düzeylerindeki fide gövde yaş ağırlıklarının, saf su ortamında yetiştirilen bitkilerin gövde yaş ağırlığından daha yüksek olduğunu, ancak tuzluluk düzeyinin $8 \mathrm{dS} \mathrm{m}^{-1}$ ‘den daha fazla olduğu koşullarda gövde yaş ağırlı̆̆ında önemli derecede azalmalar olduğunu belirlemiştir. Jamil ve ark. (2006), yapmış oldukları çalışmada sürgün ve kök yaş ağırlıklarında azalmanın meydana gelmesini, ortamdaki $\mathrm{Na}^{+}$ konsantrasyonun oransal olarak artması sonucunda 
Çizelge 2. Sulama suyu tuzluluk düzeylerinin ketenin sürgün ve kök yaş/kuru ağırlıkları üzerine etkilerine ilişkin veriler

\begin{tabular}{|c|c|c|c|c|c|c|c|c|}
\hline $\begin{array}{l}\text { Tuzluluk } \\
\text { Düzeyi } \\
\left(\mathrm{dS} \mathrm{m} \mathrm{m}^{-1}\right)\end{array}$ & $\begin{array}{c}\text { Sürgün } \\
\text { Yaş } \\
\text { Ağırlığ } \\
\text { (mg) }\end{array}$ & $\begin{array}{c}\text { Değişim } \\
(\%)\end{array}$ & $\begin{array}{c}\text { Sürgün } \\
\text { Kuru } \\
\text { Ağırlığ } \\
\text { (mg) }\end{array}$ & $\begin{array}{l}\text { Değişim } \\
(\%)\end{array}$ & $\begin{array}{c}\text { Kök } \\
\text { Yaş } \\
\text { Ağırlığ } 1 \\
\text { (mg) }\end{array}$ & $\begin{array}{c}\text { Değişim } \\
(\%)\end{array}$ & $\begin{array}{c}\text { Kök } \\
\text { Kuru } \\
\text { Ağırlığ } \\
\text { (mg) }\end{array}$ & $\begin{array}{c}\text { Değ ğişim } \\
(\%)\end{array}$ \\
\hline 0.38 & $553^{\mathrm{bc}}$ & 100 & $78^{\mathrm{a}}$ & 100 & $264^{\mathrm{a}}$ & 100 & $23^{a}$ & 100 \\
\hline 1 & $598^{\mathrm{ab}}$ & 108 & $85^{\mathrm{a}}$ & 109 & $271^{\mathrm{a}}$ & 103 & $24^{\mathrm{a}}$ & 103 \\
\hline 2 & $635^{\mathrm{a}}$ & 115 & $87^{\mathrm{a}}$ & 111 & $291^{\mathrm{a}}$ & 110 & $26^{\mathrm{a}}$ & 111 \\
\hline 3 & $529^{\mathrm{cd}}$ & 96 & $65^{\mathrm{b}}$ & 83 & $213^{\mathrm{b}}$ & 81 & $18^{\mathrm{b}}$ & 80 \\
\hline 4 & $479^{\mathrm{de}}$ & 87 & $52^{c}$ & 66 & $194^{\mathrm{bc}}$ & 73 & $18^{\mathrm{b}}$ & 77 \\
\hline 5 & $436^{\mathrm{ef}}$ & 79 & $50^{\mathrm{c}}$ & 64 & $177^{\mathrm{bc}}$ & 67 & $17^{\mathrm{bc}}$ & 71 \\
\hline 6 & $420^{\text {efg }}$ & 76 & $50^{\mathrm{c}}$ & 63 & $165^{\mathrm{c}}$ & 63 & $15^{\mathrm{c}}$ & 64 \\
\hline 7 & $397^{\text {fgh }}$ & 72 & $48^{c}$ & 61 & $125^{\mathrm{d}}$ & 47 & $11^{\mathrm{d}}$ & 48 \\
\hline 8 & $370^{\text {ght }}$ & 67 & $45^{\mathrm{cd}}$ & 58 & $96^{\mathrm{de}}$ & 36 & $8^{\mathrm{de}}$ & 36 \\
\hline 9 & $343^{\text {hl }}$ & 62 & $38^{\mathrm{de}}$ & 48 & $95^{\mathrm{de}}$ & 36 & $8^{\mathrm{e}}$ & 34 \\
\hline 10 & $319^{1}$ & 58 & $33^{\mathrm{e}}$ & 42 & $77^{\mathrm{e}}$ & 29 & $6^{\mathrm{e}}$ & 26 \\
\hline LSD & $61.7^{*}$ & & $9.5^{*}$ & & $40.1^{*}$ & & $2.8^{*}$ & \\
\hline VK & 9.26 & & 10.52 & & 8.41 & & 12.73 & \\
\hline
\end{tabular}

ozmotik ve iyon dengesinin bozulmasindan kaynaklanabileceğini tespit etmişlerdir.

\subsection{Sürgün ve kök kuru ăgırlı̆g}

Tuz seviyelerine göre sürgün kuru ağırlıkları $33 \mathrm{mg}$ ile $87 \mathrm{mg}$ arasında değişim göstermiş, en yüksek sürgün kuru ağırlığ sürgün kuru ağırlığ 1 ise $10 \mathrm{dS} \mathrm{m}^{-1}$ tuz seviyesinde elde edilmiştir. Sürgün kuru ağırlığında $2 \mathrm{dS} \mathrm{m}^{-1}$ tuzluluk düzeyine kadar artış görülürken, $2 \mathrm{dS} \mathrm{m}^{-1}$ tuzluluk seviyesinden sonra tuzluluk düzeyinin artmasiyla birlikte azalma görülmüştür (Çizelge 2).

Kök kuru ağırlıkları tuzluluk seviyesine bağlı olarak $6 \mathrm{mg}$ ile $26 \mathrm{mg}$ arasında değişim göstermiştir (Çizelge 2). Sürgün kuru ağırlığına benzer olarak kök kuru ağırlığında da $2 \mathrm{dS} \mathrm{m}^{-1}$ tuzluluk seviyesine kadar artışın meydana geldiği belirlenmiştir. Kök kuru ağırlı̆g 1 bakımından kontrol, 1 ve $2 \mathrm{dS} \mathrm{m}^{-1}$ tuzluluk seviyeleri arasındaki farklılığın \%1 düzeyine göre önemli olmadığı saptanmıştır. Tuz stresine bağlı olarak yaş ağırlıkta meydana gelen artış ve azalışa paralel olarak kuru ağırlıklarda da benzer sonuçlar elde edilmiştir.

\subsection{Sürgün uzunluğu}

Farklı sulama suyu tuzluluğunda sürgün uzunluklarındaki değişimin 1.7 ile $4.6 \mathrm{~cm}$ arasında olduğu belirlenmiştir. En uzun sürgün uzunluğu $4.6 \mathrm{~cm}$ ile $2 \mathrm{dSm}^{-1}$ tuzluluk seviyesinden elde edilirken, en kısa sürgün uzunluğu ise $1.7 \mathrm{~cm}$ ile $10 \mathrm{dS} \mathrm{m} \mathrm{m}^{-1}$ tuzluluk seviyesinde elde edilmiştir. Kontrol $\left(0.38 \mathrm{dS} \mathrm{m}^{-1}\right)$ ile $2 \mathrm{dS} \mathrm{m^{-1 }}$ tuzluluk seviyesi arasında sürgün uzunluğu bakımından \% 21.0'lik bir artışın olmasına karşın
$2 \mathrm{dS} \mathrm{m} \mathrm{m}^{-1}$ tuzluluk seviyesi ile $10 \mathrm{dS} \mathrm{m}^{-1}$ tuzluluk seviyesi arasında \%77.0 oranında bir azalmanın olduğu belirlenmiştir (Çizelge 3). Benzer biçimde tuzluluk düzeyinin artmasına bağlı olarak sürgün uzunluğunun azaldığı çeşitli araştırıcılar tarafindan ortaya konmuştur (Kara ve ark., 2011; Benlioğlu ve Özkan, 2015).

\subsection{Kök uzunluğu}

Araştırma sonucunda farklı tuzluluk koşullarının ketenin kök uzunluğu üzerine etkisinin $\mathrm{P}<0.01$ düzeyinde önemlilik arz ettiği belirlenmiştir. Tuz seviyesine bağlı olarak kök uzunlukların konulara göre 2.5 ile $14.5 \mathrm{~cm}$ arasında değişim gösterdiği, kök uzunluğunun en fazla $2 \mathrm{dS} \mathrm{m}^{-1}$ tuz seviyesinde ve en kısa kök uzunluğunun ise $10 \mathrm{dS} \mathrm{m}^{-1}$ tuz seviyesinde olduğu belirlenmiştir. Tuz seviyesine bağlı olarak en uzun ve en kısa kök uzunluğu dikkate alındığında kök uzunluğundaki azalmanın \% 95.0 oranında olduğu belirlenmiştir. Sürgün uzunluğu değerlerine benzer biçimde, kök uzunluğu değerleri de $2 \mathrm{dSm}^{-1}$ tuzluluk seviyesine kadar tuz stresi, tohumda toksik etki oluşturmadan kök uzunluğunun artmasını sağlamış, 2 $\mathrm{dSm}^{-1}$ tuz seviyesinden sonra ise tuz stresi arttıkça kök uzunluğunda azalma meydana geldiği tespit edilmiştir (Çizelge 3). Kaya ve ark. (2005), düşük tuz konsantrasyonlarının kök uzunluğunun artmasını teşvik ettiğgini belirlemişlerdir. Kök uzunluğu, kuraklık stresi için en önemli parametrelerden birisi olup, kökler toprak ile temasa geçtiğinde bitkinin ihtiyacı olan suyun topraktan emilmesini sağlamaktadırlar (Mostafavive ark., 2011). Zaghdoudi ve ark. (2015), yaptıkları çalışmada O116 ve P126 keten çeşitlerinin, $250 \mathrm{mM}$ tuzluluk düzeyinde kök uzunluklarının, \% 85.0 oranında 
azaldığını tespit etmişlerdi.

Elde edilen bilgilerin ışığında, tuz stresinin, köklerin su ve besin dengesinin bozulmasina neden olarak, köklerin uzamasını ve büyümesini engellediği söylenebilir. Jafarzadeh ve Aliasgharzad (2007) şeker pancarında, Akbari ve ark. (2007) buğdayda, Day ve ark. (2009) kolzada ve Kaya ve ark. (2012) ketende yaptıkları araştırmalarda kök uzunluğunun tuz stresine bağlı olarak azaldığını belirlemişlerdir.

Çizelge 3. Sulama suyu tuzluluk düzeylerinin keten sürgün ve kök uzunluğu üzerine etkilerine ilişkin veriler

\begin{tabular}{|c|c|c|c|c|}
\hline $\begin{array}{l}\text { Tuzluluk Düzeyi } \\
\qquad\left(\mathrm{dS} \mathrm{m} \mathrm{m}^{-1}\right)\end{array}$ & $\begin{array}{l}\text { Sürgün Uzunluğu } \\
(\mathrm{cm})\end{array}$ & $\begin{array}{l}\text { Değişim } \\
(\%)\end{array}$ & $\begin{array}{l}\text { Kök Uzunluğu } \\
(\mathrm{cm})\end{array}$ & $\begin{array}{l}\text { Değişim } \\
(\%)\end{array}$ \\
\hline 0.38 & $3.8^{\mathrm{abc}}$ & 100 & $12.7^{\mathrm{bc}}$ & 100 \\
\hline 1 & $4.4^{\mathrm{ab}}$ & 115 & $14.2^{\mathrm{ab}}$ & 112 \\
\hline 2 & $4.6^{\mathrm{a}}$ & 121 & $14.53^{\mathrm{a}}$ & 115 \\
\hline 3 & $3.8^{\mathrm{bc}}$ & 99 & $11.9^{\mathrm{cd}}$ & 94 \\
\hline 4 & $3.2^{\mathrm{cd}}$ & 84 & $10.2^{\text {de }}$ & 81 \\
\hline 5 & $3.1^{\mathrm{cd}}$ & 80 & $10.1^{\mathrm{e}}$ & 80 \\
\hline 6 & $2.8^{\mathrm{de}}$ & 72 & $8.9^{\mathrm{ef}}$ & 71 \\
\hline 7 & $2.6^{\mathrm{de}}$ & 68 & $7.4^{\mathrm{fg}}$ & 59 \\
\hline 8 & $2.5^{\mathrm{de}}$ & 66 & $6.5^{\mathrm{g}}$ & 51 \\
\hline 9 & $2.2^{\mathrm{ef}}$ & 58 & $4.3^{\mathrm{h}}$ & 34 \\
\hline 10 & $1.7^{\mathrm{f}}$ & 44 & $2.5^{1}$ & 20 \\
\hline LSD & $0.8^{*}$ & & $1.7^{*}$ & \\
\hline VK & 13.35 & & 12.56 & \\
\hline
\end{tabular}

\subsection{Fide gelişim parametreleri arasındaki ilişkiler}

Çizelge 4'te farklı tuz seviyelerindeki, keten fide gelişim parametreleri arasındaki ilişkiler verilmiştir. Çizelge 4 incelendiğinde; sürgün yaş ağırlığı ile kök yaş ağırlığı, sürgün ve kök kuru ağırlıkları, sürgün ve kök uzunlukları arasındaki korelasyonun \% 1 seviyesinde önemli olduğu saptanmıştır. Kök yaş ağırlığı ile kök ve sürgün uzunluğu ile kök ve sürgün kuru ağırlıkları arasındaki ilişkinin \% 1 düzeyinde önemli olduğu tespit edilmiştir.
Sürgün kuru ağırlığı ile fide gelişim parametreleri arasında pozitif bir ilişki olduğu, sürgün kuru ağırlığ1 arttıkça sürgün ve kök uzunluğu ile kök kuru ağırlığının arttığı belirlenmiştir. Ayrıca kök uzunluğu ile sürgün uzunluğu ve kök kuru ağırlığı ile kök ve sürgün uzunluğu arasında \% 1 düzeyinde önemli bir ilişkinin olduğu ve kök kuru ağırlığının artması ise fide gelişim özelliklerinin olumlu yönde etkilediği belirlenmiştir (Çizelge 4).

Çizelge 4. Keten tohumlarının fỉde gelişim parametreleri arasındaki korelasyon katsayılarına ilişkin veriler

\begin{tabular}{|c|c|c|c|c|c|c|}
\hline Karakterler & $\begin{array}{c}\text { Sürgün yaş } \\
\text { ağırlı̆̆ı }(\mathrm{mg})\end{array}$ & $\begin{array}{l}\text { Kök yaş } \\
\text { ağırlığ1 } \\
\text { (mg) }\end{array}$ & $\begin{array}{l}\text { Sürgün kuru } \\
\text { ağırlığ1 } \\
\text { (mg) }\end{array}$ & $\begin{array}{l}\text { Kök kuru } \\
\text { ağırlığ1 } \\
\text { (mg) }\end{array}$ & $\begin{array}{l}\text { Kök uzunluğu } \\
(\mathrm{cm})\end{array}$ & $\begin{array}{l}\text { Sürgün } \\
\text { uzunluğu } \\
\text { (cm) }\end{array}$ \\
\hline $\begin{array}{l}\text { Sürgün yaş } \\
\text { ağırlığı (mg) }\end{array}$ & 1 & $0.894^{* *}$ & $0.938^{* *}$ & $0.922^{* *}$ & $0.872^{* *}$ & $0.819^{* *}$ \\
\hline $\begin{array}{r}\text { Kök yaş } \\
\text { ağırlığ1 (mg) }\end{array}$ & & 1 & $0.864^{* *}$ & $0.980^{* *}$ & $0.898^{* *}$ & $0.768^{* *}$ \\
\hline $\begin{array}{l}\text { Sürgün kuru } \\
\text { ağırlığı (mg) }\end{array}$ & & & 1 & $0.882^{* *}$ & $0.872^{* *}$ & $0.807^{* *}$ \\
\hline $\begin{array}{r}\text { Kök kuru } \\
\text { ağırlığı (mg) }\end{array}$ & & & & 1 & $0.919^{* *}$ & $0.799^{* *}$ \\
\hline $\begin{array}{l}\text { Kök uzunluğu } \\
\quad(\mathrm{cm})\end{array}$ & & & & & 1 & $0.804^{* *}$ \\
\hline $\begin{array}{c}\text { Sürgün } \\
\text { uzunluğu }(\mathrm{cm})\end{array}$ & & & & & & 1 \\
\hline
\end{tabular}




\section{Sonuç}

Farklı sulama suyu tuzluluk seviyesine sahip ortamların ketenin çimlenme ve fide gelişim parametreleri üzerine olan etkilerinin incelendiği bu araştırmada; en yüksek çimlenme oranı ve tuz toleransı indeksi değerleri sırasıyla \% 97.0 ve $\% 112.0$ ile 2 $\mathrm{dS} \mathrm{m}^{-1}$ tuzluluk seviyesinden elde edilmiştir. Tuz içeriğinin $5 \mathrm{dS} \mathrm{m}^{-1}$ düzeyine kadar arttırılmasının çimlenme hızında istatistiksel olarak önemli farklılık oluşturmadığı, bununla birlikte en yüksek fide gelişim parametrelerinin $2 \mathrm{dSm}^{-1}$ tuzluluk düzeyinde olduğu belirlenmiştir.Kontrollü şartlar altında elde edilen bu sonuçların, daha uzun süreli ve kapsamlı tarla denemeleri ile desteklenmesi, ayrıca, farklı sulama suyu tuzluluk seviyelerinin, ülkemizin bitkisel yağ açığını azaltma bakımından potansiyel öneme sahip olan keten bitkisinin verim ve verim unsurları ile yağ içeriği ve diğer teknolojik parametreleri üzerindeki etkilerinin de araştırılması gerekmektedir. Böylece küresel ısınma ve yağış rejiminde meydana gelen değişiklikler sonucunda tuzlu alanların artmakta olduğu dikkate alındığında; bu tip alanlarda yetiştirilebilecek ve yüksek verim sağlanabilecek yağ bitkilerinin üretime alınabilmesi açısından keten bitkisinin potansiyel değerinin daha iyi tespit edilmesi mümkün olacaktır.

\section{Kaynaklar}

Akbari, G., Modarres Sanavy, S.A.M., Yousefzadeh, S., 2007. Effect of auxinand salt stress ( $\mathrm{NaCI})$ on seed germination of wheat cultivars (Triticum aestivum L.). Pakistan Journal of Biological Sciences, 10(15): 2557-2561.

Aşçı, Önal, Özlem., Üney, H., 2016. Farklı tuz yoğunluklarının macar fiğinde (Vicia pannonica Crantz) çimlenme ve bitki gelişimine etkisi. Akademik Ziraat Dergisi, 5(1): 29-34.

Aydinşakir, K., Erdal, Ş., Pamukçu, M., 2013. The effects of different salt concentrations on germination and seedling parameters of silage corn (Zea Mays L.) varieties. Anadolu Journal of Agricultural Sciences, 28(2): 94-100.

Aydınşakir, K., Erdurmuş, C., Büyüktaş, D., Çakmakcı, S., 2012. Tuz $(\mathrm{NaCl})$ stresinin bazı silajlık sorgum (Sorghum bicolor) çeşitlerinin çimlenme ve erken fide gelişimi üzerine etkileri. Medıterranean Agricultural Sciences, 25(1): 47-52.

Ayers, R.S., Wescot, D.W., 1989. Water quality for agriculture. Irrigation and Drainageas Papper, No:29, FAO, Rome, p174.

Benlioğlu, B., Özkan, U., 2015. Bazı arpa çeşitlerinin (Hordeum vulgare L.) çimlenme dönemlerinde farklı dozlardaki tuz stresine tepkilerinin belirlenmesi. Tarla Bitkileri Araştırma Enstitüsü Dergisi, 24(2): 109-114.
Bozkurt, D., Kurt, O., 2007. Keten (Linum usitatissimum L.)'in verim ve verim unsurlarına ekim zamanı ve toprak sıcaklığının etkisi. Ondokuz Mayıs Üniversitesi Ziraat Fakültesi Dergisi, 22(1): 20-25.

Castroluna, A., Ruiz, O.M., Quiroga, A.M., Pedranzani, H.E., 2014. Effects of salinity and drought stress on germination, biomass and growth in three varieties of Medicago sativa L. Advances en Inventigacion Agropecuria, 18(1): 39-50.

Çiftçi, Aydoğan, E., Kurt, Ö. P., Yağd1, K., 2013. Farklı tuz konsantrasyonlarının triticale çeşitlerinin çimlenmesi üzerine etkileri. Uludağ Üniversitesi Ziraat Fakültesi Dergisi, 27(2): 1-11.

Çulha, Ş., Çakırlar, H., 2011. Tuzluluğun bitkiler üzerine etkileri ve tuz tolerans mekanizmaları. Afyon Kocatepe Üniversitesi Fen ve Mühendislik Bilimleri Dergisi, 11(2): 11-34.

Day, S., Kaya, M.D., Kolsarıcı, Ö., 2009. Bazı yazlık ve kışlık kolza (Brassica napus ssp. oleifera) çeşitlerinin çimlenme ve çıkışı üzerine $\mathrm{NaCl}$ konsantrasyonlarının etkisi. Türkiye VIII. Tarla Bitkileri Kongresi, Bildiriler (I): 19-22 Ekim, Hatay, s: 225-228.

Ekmekçi, E., Apan, M., Kara, T., 2005. Tuzluluğun bitki gelişimine etkisi. OMÜ Ziraat Fakültesi Dergisi, 20(3):118-125.

ISTA, 2003. Handbook of Vigour Test Methods. 2nd Edition. International Seed Testing Association (ISTA), Zürich, Switzerland. 49-56.

Gholizadeh, F., Manzari-Tavakkoli, A., Pazoki, A., 2016. Evaluation of salt tolerance on germination stage and morphological characteristics of some medicinal plants artichoke, flax, safflower and coneflower. International Journal of Farming and Allied Sciences, 5(3): 229-237.

Gill, P.K., Sharma, A.D., Singh, P., Bhullar, S.S., 2003. Changes in germination, growth and soluble sugar contents of sorghum bicolor L. Moench seeds under various abiotic stresses. Plant Growth Regulation, 40: 157-162.

Jafarzadeh, A., Aliasgharzad, N., 2007. Salinity and salt composition effects on seed germination and root length of four sugarbeet cultivars. Biologia, 62(5): 562-564.

Jamil, M., Lee, D.B., Jung, K.Y., Ashraf, M., Lee, S.C., Rha, E.S., 2006. Effect of salt (NaCI) stress on germination and early seedling growth of four vegetables. Journal of Central European Agriculture, 7(2): 273-282.

Kara, B., Akgün, İ., Altındal, D., 2011. Tritikale genotiplerinde çimlenme ve fide gelişimi üzerine tuzluluğun $(\mathrm{NaCI})$ etkisi. Selçuk Tarım ve Gıda Bilimleri Dergisi, 25(1): 1-9. 
Kaya, M. D., İpek, A., Öztürk, A., 2003. Effects of different soil salinity levels on germination and seedling growth of safflower. Turkish Journal of Agriculture and Forestry, 27: 221-227.

Kaya, M. D., Kaya, G., Kolsarıc1, Ö., 2005. Bazı Brassica türlerinin çimlenme ve çıkışı üzerine $\mathrm{NaCl}$ konsantrasyonlarının etkisi. Tarım Bilimleri Dergisi-Journal of Agricultural Sciences, 11(4): 448-452.

Kaya, D.M., Day, S., Cikili, Y., Arslan, N., 2012. Classification of some linseed (Linum usitatissimum L.) genotypes for salinity tolerance using germination, seedling growth, and ion content. Chilean Journal of Agricultural Research, 72(1): 27-32.

Kuşvuran, Ş., Ellialtıoğlu, Ş., Abak, K., Yaşar, F., 2007. Bazı kavun (Cucumis sp.) genotiplerinin tuz stresine tepkileri. Tarım Bilimleri Dergisi, 13(4): 395-404

Kurt, O., 1996. Ketenin üretim ve kullanımı. OMÜ Zir. Fak. Dergisi, 11(1): 189-194.

Levitt, J., 1980. Responses of plants to environmental stresses: Volume 2-Water, radiation, salt and other stresses. Acedemic Press, New York, 365-488.

Mahmoodzadeh, H., 2008. Comperative study of tolerant and sensitive cultivars of Brassica napus in response to salt conditions. Asian Journal of Plant Sciences, 7(6): 594-598.

Mansour, M. M. F., 1994. Changes in growth, osmotic potential and cell permeability of wheat cultivars under salt stress. Biologica Plantarum, 36: 429434.

Matwijcuk, A., Kornarzynski, K., Pietruszewski, S. 2012. Effect of magnetic field on seed germination and seedling growth of sunflower. International Agrophysics, 26: 271-278.

Munns, R., 2005. Genes and salt tolerance: bringing them together. New Phytologist, 167: 645-663.

Tabatabaei, S. A., Anagholi, A., 2012. Effect of salinity on some characteristics of forage sorghum genotypes at germination stage. International Journal of Agriculture and Crop Sciences, 4(14): 979-983.

Odabaş, M.S., Temizel, K.E., Çalışkan, O., Senyer, N., Kayhan, G., Ergün, E., (2014). determınation of reflectance values of hypericum's leaves under stress conditions using adaptive network based fuzzy inference system. Neural Network World, 1(14): $79-87$.
Temizel, K.E., Odabas, M.S., Senyer, N., Kayhan, G., Bajwa, S., Caliskan, O., Ergun, E., 2014. Comparision of some models for estimation of reflectance of hypericum leaves under stress conditions. Central European Journal of Biology, 9(12): 1226-1234.

Temizel, K.E., 2015. Estimation of the phenolics content of St. John's Wort (Hypericum perforatum L.) grown under different water and salt levels based on reflectance spectroscopy. Kuwait Journal of Science, 42(3): 210 -222.

Turhan, H., Başeri, İ., 2001. Toprak tuzluluğu ve bitki gelişimi. Akdeniz Üniversitesi Ziraat Fakültesi Dergisi, 14(1): 171.179 .

TÜIK, 2015. Bitkisel üretim istatistikleri. https://biruni.tuik.gov.tr/bitkiselapp/bitkisel.zul. (Erişim tarihi 23.05.2016).

Uyanık, M., Kara, M.Ş., Korkmaz, K., 2014. Bazı kışlık Kolza (Brassica napus L.) çeşitlerinin çimlenme döneminde tuz stresine tepkilerinin belirlenmesi. Tarım Bilimleri Dergisi, 20: 368-375.

Yıldız, M., Kasap, E., Konuk, M., 2007. Tuzluluk, sıcaklık ve 1şı̆̆ın tohum çimlenmesi üzerine etkileri. Afyon Kocatepe Üniversitesi Fen Bilimleri Dergisi, 7(1): 225-243.

Zamani, S., Nezami, M.T., Habibi, D., Khorshidi, M.B., 2010. Effect of quantitive and qualitative performance of four canola cultivars (Brassica napus L.) to salinity conditions. Advances in Environmental Biology, 4(3): 422-427.

Zaghdoudi, M., Baatour, O., Bensalem, N., Ouerghi Abidi, Z., 2015. Effect of saline conditions on germination and enzymatic activity in two varieties of L. usitatissimum seeds. Journal of New Sciences, 17(6): 629-638. 